\title{
THE DEVELOPMENT OF A UNIVERSAL TRANSFORMER HOUSING OF THE UNIT TRANSFORMER SUBSTATION 6-10 / 0.4 KV
}

\author{
Dmitry Vladimirovich Malygin ${ }^{1}$, Maksim Vladimirovich Borodin ${ }^{2,}$, Roman Pavlovich Belikov ${ }^{3}$, Yulia Lyusievna \\ Mikhaylova $^{4}$, and Zumeyra Munirovna Shakurova ${ }^{5}$ \\ ${ }^{1}$ Head of the Livensky district electrical networks of the Rosseti Center Orelenergo branch, Livny, Russia \\ ${ }^{2} \mathrm{Ph}$.D. (Engineering), Associate Professor, Head of the Department of electric power supply, FSBEE HE Oryol state agrarian university \\ named after N. I. Parakhin, Oryol, Russia \\ ${ }^{3} \mathrm{Ph} . \mathrm{D}$. (Engineering), Associate Professor of the chair of electric power supply, FSBEE HE Oryol state agrarian university named after \\ N. I. Parakhin, Oryol, Russia \\ ${ }^{4}$ Ph.D. (Philology), Associate Professor, Head of the Department of Linguistics and Humanities, FSBEE HE Oryol state agrarian \\ university named after N. I. Parakhin, Oryol, Russia \\ ${ }^{5}$ Ph.D., Associate Professor of the Department "Power Supply of Industrial Enterprises" of Kazan State Power Engineering University, \\ Kazan, Russia
}

\begin{abstract}
The company group of the PJSC "ROSSETI" pays great attention to reducing occupational hazard at the facilities of the power grid complex. The analysis of the accidents in the branch of PJSC "IGDC of the Center"- "Orelenergo" revealed that transformer housings installed at the mast-type transformer substations 6-10/0.4 kV can't fully provide the required safety level as they can be slightly raised even without using a special tool, and therefore one can stick his hands or some objects to the current-carrying parts of the transformer substation. According to the statistics of the damages at the masttype transformer substations 6-10/0.4 kV various small animals and birds can enter the electrical installation through small slits between the housing and the transformer, which will lead to different emergency situations. To prevent the aforementioned negative consequences, a universal transformer housing was developed for a mast-type unit transformer substation (UTS) 6-10 / 0.4 kV. The offered design of the housing is universal, since it can be used for the transformers of various capacities; for its manufacture tools and materials with different characteristics can be used. At the same time, the installation of the developed housing will allow power grid companies to reduce occupational hazard, reduce the undersupply of electricity and increase the reliability of power supply to the agricultural consumers. The technical solution presented in the article can be applied for the mast-type UTS 6-10 / $0.4 \mathrm{kV}$ in the postSoviet countries.
\end{abstract}

\section{Introduction}

The scientific work of the authors [1-4] indicates that the level of industrial injuries is one of the most important problems in the electric power industry. In the works of the authors [5-9] it is indicated that significant funding is allocated to the power grid companies for the implementation of programs aimed at reducing occupational hazard of the personnel at the facilities of the power grid complex. Reducing the level of injuries in the power grid organizations allows to save lives, decreasing the undersupply of electricity and increasing the reliability of electricity supply to consumers.

It should be noted that Russia and a number of postSoviet countries continues use mast-type unit transformer substations (UTS) 6-10/ $0.4 \mathrm{kV}$. The operation of this type of UTS is characterized by rather a low safety level due to the fact that there is no universally designed transformer housing to protect the personnel of the power grid companies, as well as third parties and animals from getting to the current-carrying parts of the UTS $6-10 / 0.4 \mathrm{kV}$.

In general, the company group of the PJSC "ROSSETI" and PJSC "IGDC of the Center" in particular, pay great attention to the issues of reducing occupational hazard at the serviced facilities. At present, a large number of programs and organizational and administrative documents have been developed in Russia that regulates this work. Meanwhile, it should be noted that the statistics on the accidents of the third-party injuries remains disappointing.

\section{Theoretical research}

In the course of the analysis of accidents in the branch of PJSC "IGDC of the Center"-“Orelenergo", the authors

\footnotetext{
* Corresponding author: maksimka-borodin@yandex.ru
} 
revealed that the transformer housings installed at the mast-type UTS 6-10 / $0.4 \mathrm{kV}$ (Figure 1) do not fully provide the required safety level as they can be raised without using a special tool, one can stick his hands and all kinds of objects to the current-carrying parts of the UTS.

At the same time, according to the statistics of the damages at the mast-type UTS, small animals and birds penetrate into these electrical installations through rather large slits between the housing and the transformer, which leads to the emergencies.

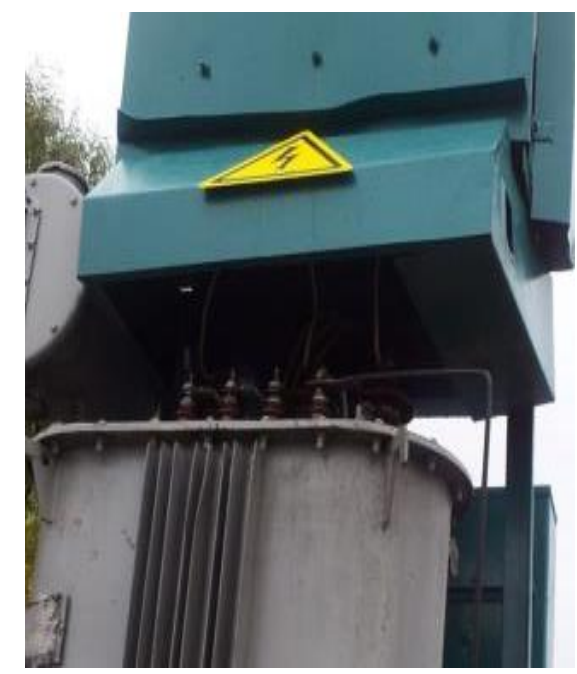

Fig. 1. Photo of the transformer housing installed at the 6-10 / $0.4 \mathrm{kV}$ mast-type UTS of the branch of "IGDC of the Center" "Orelenergo".

The restoration of the UTS after birds or other small animals' penetration to the current-carrying parts of the UTS is of great importance for the power grid companies, since a significant amount of time is spent on it. repair work and the power grid company does get profit from the sale of its services [10-14].

At the same time, the consumers are disconnected during the repair work and the power grid company does get profit from the sale of its services [10-14].

When developing a new transformer housing for the existing mast-type UTS $6-10 / 0.4 \mathrm{kV}$, the following requirements must be taken into account:

- the developed housing, when changing its geometric dimensions, should be suitable for the UTS 6$10 / 0.4 \mathrm{kV}$ of different power levels, i.e. housing versatility;

- the installation of the transformer housing at the UTS 6-10 / $0.4 \mathrm{kV}$ should take little time to minimize the service disconnect time;

- the possibility to produce the housing by the personnel of the district electrical networks;

- the possibility of quick fitting-up at the installation site;

- the design of the housing must be vandal-proof, enclosed and reliable.

The installation of new housings on the existing mast-type UTS 6-10 / $0.4 \mathrm{kV}$ will allow the power grid companies to reduce the number of occupational hazard and reduce the service disconnect, which in its turn will lead to an increase in the power supply reliability.

\section{Practical implementation}

To solve the abovementioned problem, a new universal housing was developed, which makes it possible to exclude penetration to the current-carrying parts of the mast-type UTS 6-10 / $0.4 \mathrm{kV}$. A sketch of the developed housing construction is shown in Figure 2.

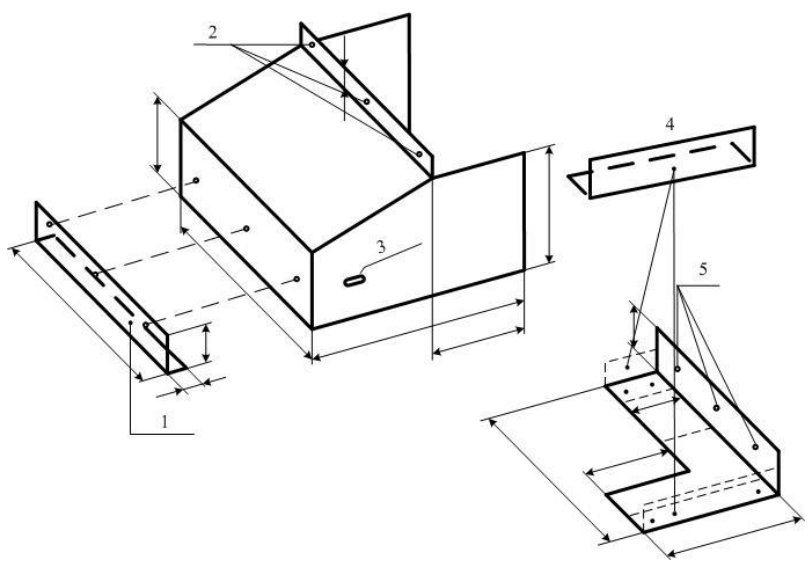

Fig. 2. The sketch of the construction of a universal transformer housing for the mast-type UTS 6-10 / $0.4 \mathrm{kV}$ (1 Angle bar (inserted inside the housing and fastened with rivets); 2 - Bores for attaching the housing to the UTS (screws, bolts, nuts inside); 3 - Bores for fastening (adjusted at the place of installation); 4 - Angle bar for fastening (made during the manufacture of the housing on-the-site from the already-curved angle); 5 - Bores for the screws (bolts) fastening the housing to the UTS body (drilled when installing the housing at the installation site)).

Before manufacturing the transformer housing construction, the employees of the power grid company draw up a sketch. To do this, the workers go to the masttype UTS and make the necessary measurements, then transfer them to the sketch. Further, according to this sketch, the components are manufactured and the housing is fitted. The drawn sketch simplifies the measurement process and eliminates errors of possible low engineering qualifications of the workers. The manufacturing of the housing takes little time and does not require special skills of the personnel.

The universal housing is mounted on the transformer substation using rivets and a riveter. The use of rivets makes the housing vandal-proof. The housing is attached to the UTS body with the help of screws or bolts with the nuts inside.

The absence of the fundamental difficulties in the manufacturing of the housing allows it to be produced by the employees of the district power station without the involvement of third-party organizations. To implement the housing shown in Figure 2, necessary for its manufacturing materials and equipment are selected. The necessary materials are: sheet steel 1-2mm; paint - paint primer GF; enamel paint (corporate colors); self-tapping screws; rivets; a plastic sign "Stop. High voltage" and a sign "death's-head", electrodes. The tools and devices 
are: tin snips; angle grinder; compressor with spray gun; bench work tools; a wrench set; a riveter; a bending machine (if available); a welding machine.

All the necessary materials and equipment for the manufacturing of the developed housing of the mast-type UTS 6-10 / $0.4 \mathrm{kV}$ are presented without names and characteristics. Thee equipment and materials of various brands and with different characteristics can be used in the manufacturing and installation of the developed housing. The mentioned above indicates that the manufacturing of the developed transformer housing of the mast-type UTS $6-10 / 0.4 \mathrm{kV}$ is universal.

On the basis of the sketch presented in Figure 2, "rough" and "final" versions of the mast-type transformer housing UTS 6-10 / $0.4 \mathrm{kV}$ were manufactured and mounted. They are presented in Figure 3 and 4 respectively.

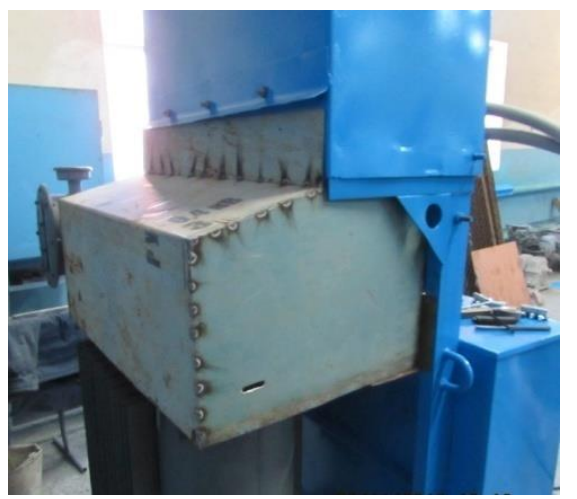

Fig. 3. Photo of a "rough" version of the mast-type transformer housing of the UTS $6-10 / 0.4 \mathrm{kV}$.

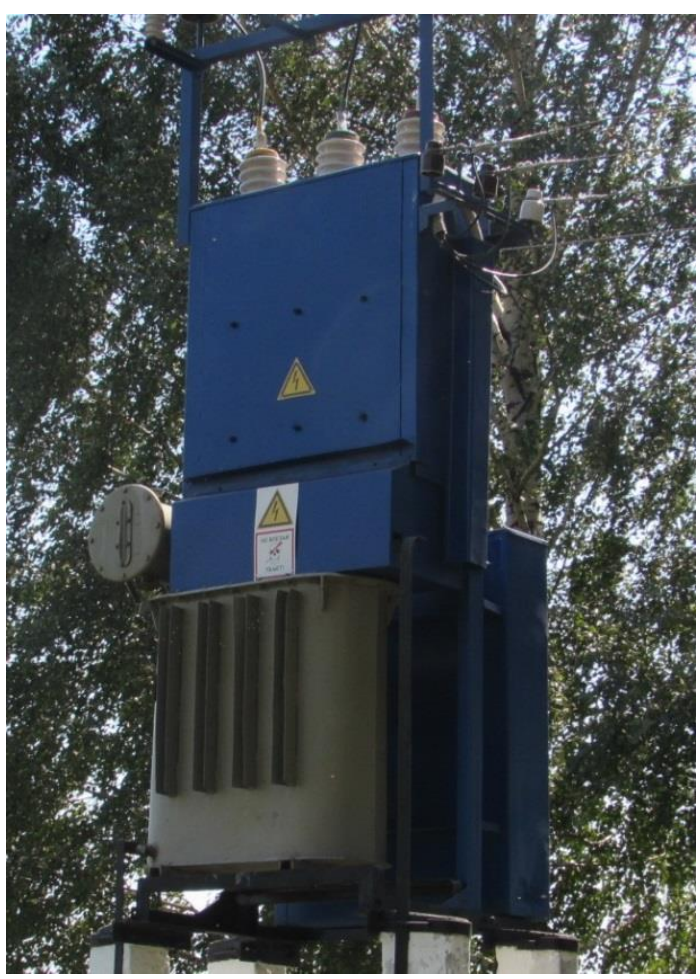

Fig. 4. Photo of the "final" version of the mast-type transformer housing of the UTS 6-10 / $0.4 \mathrm{kV}$.
In the photo shown in Figure 4, a plate (bottom) of the housing is visible on top of the transformer, which also allows preventing various elements from penetrating into the transformer from under the housing and making it safer and more enclosed.

The developed universal mast-type transformer housing of the UTS $6-10 / 0.4 \mathrm{kV}$ was accepted by the branch of "IDGC of the Center" - "Orelenergo" as an rationalization proposal and will be applied in the company.

\section{Conclusions}

The technical solution presented in the article can be applied for the mast-type UTS 6-10/ $0.4 \mathrm{kV}$ at all standard UTSs. The proposed design of the housing is universal, since it can be used for the transformers of various capacities. The manufacturing of a universal housing allows to use materials and tools with different characteristics.

The developed sketch of the housing construction for the mast-type UTS $6-10 / 0.4 \mathrm{kV}$ makes it possible to simplify significantly the measurement process and eliminate errors of possible low engineering qualifications of the employees of the power station.

The developed transformer housing for the mast-type UTS $6-10 / 0.4 \mathrm{kV}$ allows to reduce the possibility of penetration of the third parties, birds and small animals to the terminals of the transformer, which, in its turn, gives the right to consider it an important technical improvement with a sufficient level of reliability and usefulness.

The introduction of the presented technical solution will allow power grid companies to reduce the risk of injuries for the third parties, save lives both of the personnel and third parties, as well as reduce the shortage of electricity and improve the reliability of the power supply to the consumers.

\section{References}

1. Denisov E.I. Numerical scale for work-relatedness assessment of a disease Abstr. XIV Int. Conf. on Epidemiol, in Occup. Health. - Herzlia, 1999. - P. 137.

2. Gavrichenko A.I., Belikov R.P. Scientific bases of the occupational risks [Text]: monograph. Oryol: Oryol state agrarian university. 2013.107 p. (Gavrichenko A.I., Belikov R.P. Nauchnye osnovy professional'nyh riskov [Tekst]: monografiya. Orel: Orlovskij gos. agrarnyj un-t. 2013. 107 s.)

3. Gavrichenko A.I. Professional risk management [Text] / Gavrichenko A.I., Belikov R.P. // Agrotechnics and energy supply. 2015. No. 2 (6). P. 69-75. (Gavrichenko A.I. Upravlenie professional'nymi riskami [Tekst] / Gavrichenko A.I., Belikov R.P. // Agrotekhnika I energoobespechenie. 2015. No. 2 (6). S. 69-75.)

4. Gavrichenko A.I. Identification of the dynamics of the occupatonal risks according to the statistical data 
[Text] / Gavrichenko A.I., Belikov R.P. // Agrotechnics and energy supply. 2014. No. 1 (1). P. 539-544. (Gavrichenko A.I. Identifikaciya dinamiki professional'nyh riskov po statisticheskim dannym [Tekst] / Gavrichenko A.I., Belikov R.P. // Agrotekhnika I energoobespechenie. 2014. No. 1 (1). S. 539-544.)

5. Bukharov A.I. Electrical safety in questions and answers [Text] / Bukharov A.I. // Electrical equipment: operation and repair. 2010. No. 3. P. 6372. (Buharov A.I. Elektrobezopasnost 'v voprosah I otvetah [Tekst] / Buharov A.I. // Elektrooborudovanie: ekspluataciya i remont. 2010. No. 3. S. 63-72.)

6. Drobyazko O.N. Fundamentals of electrical safety theory: current state and development prospects [Tekst] / O.N. Drobyazko // Russian Electrical Engineering. 2018. Vol. 89.No. 12. P. 728-732.

7. Vasilenko M.A. Strategic management priorities of technogenic safety in the electrical industry enterprises [Tekst] / M.A. Vasilenko, N.A. Drozdov, E.L. Kuzina, Y.A. Tagiltseva, V.Y. Barashyan, A.A. Laponogova, N.A. Sheremetieva // In the collection: Proceedings of the 2019 IEEE International Conference Quality Management, Transport and Information Security, Information Technologies IT and QM and IS 2019.2019.S. 106-109.

8. Misrikhanov M.S. Touch voltage and electrical safety when maintaining overhead power transmission lines [Tekst] / M.S. Misrikhanov, A.O. Mirzaabdullaev // Power Technology and Engineering. 2020.Vol. 53.No. 5.P. 618-622.

9. Vinogradov A.V. Method and device for preventing reverse transformation at the transformer substations $10 / 0.4 \mathrm{kV}$ in case of unauthorized voltage supply to the $0.4 \mathrm{kV}$ network [Text] / A.V. Vinogradov, A.V. Vinogradov, V.E. Bolshev, A.V. Bukreev, A.A. Panfilov, M.V. Borodin, A.S. Bredikhin, S.A. Kanyus // Industrial energy. 2020.No. 7. P. 56-62. (Vinogradov AV Sposob I ustrojstvo dlya predotvrashcheniya obratnoj transformacii na transformatornyh podstanciyah $10 / 0.4 \mathrm{kv}$ pri nesankcionirovannoj podache napryazheniya $\mathrm{v}$ set '0.4 kV [Tekst] / AV Vinogradov, AV Vinogradova, VE VE , MV Borodin, AS Bredihin, SA Kanyus // Promyshlennaya energetika. 2020. No. 7. S. 56-62.)

10. V.E. Bolshev, A.N. Vasilev, A.V. Vinogradov, A.E. Semenov, M.V. Borodin "Time factor for determination of power supply system efficiency of rural consumers", In the book: Handbook of Research on Renewable Energy and Electric Resources for Sustainable Rural Development Ser. "Advances in Environmental Engineering and Green Technologies" Hershey, Pennsylvania, - 2018. - P. 394-420.

11. Vinogradov A., Bolshev V., Vinogradova A., Kudinova T., Borodin M., Selesneva A. \& Sorokin N. (2019) "A System for Monitoring the Number and Duration of Power Outages and Power Quality in $0.38 \mathrm{kV}$ ", Electrical Networks. In: Vasant P.,
Zelinka I., Weber GW. (eds) Intelligent Computing \& Optimization. ICO 2018. Advances in Intelligent Systems and Computing, vol 866: 1-10. Springer, Cham.

12. Borodin M.V. Improving the quality of electricity by calculating voltage losses [Text] / M.V. Borodin, R.P. Belikov, N.V. Makhiyanova // Bulletin of Agrarian Science of the Don. 2019. No. 3 (47). P. 35-40. (Borodin M.V. Povyshenie kachestva elektroenergii posredstvom rascheta poter 'napryazheniya [Tekst] / M.V. Borodin, R.P. Belikov, N.V. Mahiyanova // Vestnikagrarnojnauki Dona. 2019. No. 3 (47). S. 35-40.)

13. Borodin M.V. Development of measures to reduce electricity losses in the branch of the "IDGC of the Center" - "Orelenergo" [Text] / M.V. Borodin, Yu.A. Volchenkov, A.V. Vinogradov // Bulletin of Agrarian Science of the Don. - 2015. - T. 4. No. 32. - P. 27-34. (Borodin, MV Razrabotka meropriyatij po sokrashcheniyu poter 'elektroenergii $\mathrm{v}$ filiale OAO "MRSK Centra" - "Orelenergo" [Tekst] / MV Borodin, YU.A. Volchenkov, AV Vinogradov // Vestnikagrarnojnauki Dona. - 2015. - 4. No. 32. - S. 27-34.)

14. Borodin M.V. Justification of the energy efficient section of the power lines with voltage deviations of $\pm 5 \%, \pm 10 \%$ [Text] / M.V. Borodin, N.S. Uryupin // Bulletin of the NGIEI. 2018. No. 2 (81). P. 20-29. (Borodin M.V. Obosnovanie energoeffektivnogo secheniya linij elektroperedach pri otkloneniyah napryazheniya $\pm 5 \%, \pm 10 \%$ [Tekst] / M.V. Borodin, N.S. Uryupin // Vestnik NGIEI. 2018. No. 2 (81). S. 20-29.). 